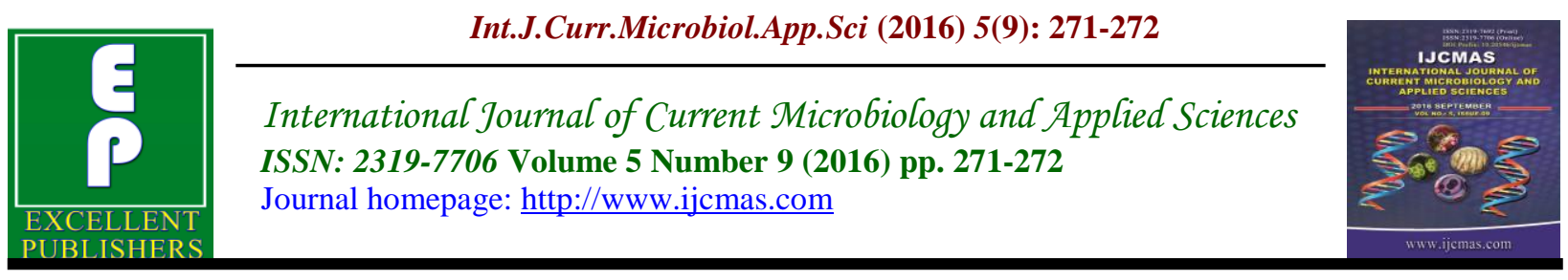

Review Article

http://dx.doi.org/10.20546/ijcmas.2016.509.030

\title{
Combating Zika Virus becomes a Global Concern
}

\author{
Shaheen Shah $^{1} *$ and R.N.S. Yadav ${ }^{2}$ \\ ${ }^{1}$ Centre for Studies in Biotechnology, Dibrugarh University, Assam, India \\ ${ }^{2}$ Department of Life Sciences, Dibrugarh University, Assam, India \\ *Corresponding author
}

A new virus called the Zika virus is spreading at a very rapid pace which is even more severe than the previous Ebola virus. This Zika virus has already spreaded to over 25 countries in Central and South America and may spread all over the world through people who have travelled to the affected regions. It has already got the declaration as a global concern by the World Health Organisation due to microcephaly condition linked to Zika virus infection. Before 2015, outbreaks of the virus have occurred in Africa, Pacific Islands and Southeast Asia. Recently outbreaks are occurring in many countries of United States with its first confirmation in Brazil [http://www.cdc.gov/zika/geo/ (accessed on February 3, 2016)].

Zika virus is a mosquito borne flavivirus first isolated from rhesus monkey in Zika forest, Uganda in 1947. In 1948, virus isolated from mosquitoes (Aedes africanas) from the same forest. In 1954, the virus was detected in humans in Nigeria.

While in 2007 and 2013, there was an outbreak in South Pacific and French Polynesia respectively. This virus is endemic in Africa and Asia [http://www.wpro.who.int/ mediacentre/ facts heets /fs_05182015_zika/en/ (accessed on January, 2016)]. In 2015, outbreaks occurred in Americas (Brazil and Colombia) and Africa (Cape Verde).

Zika virus is transmitted to humans through the bite of infected Aedes mosquitoes (Aedes aegypti in tropical regions). This mosquito also transmits dengue, chikungunya and yellow fever. People with the Zika virus disease suffer from mild fever, skin rashes, muscle and joint pain, headache and conjunctivitis which last for 2-7 days. Moreover, $80 \%$ infected cases are symptomless and therefore difficult to tract the disease.

The causative mosquito species is active during early morning and late afternoons and is expanding across the entire tropical belt due to global warming. Besides direct transmission by mosquitoes some evidence suggests indirect virus transmission to humans through blood transmission and sexual transmission although the modes are very rare [http://timesofindia.indiatimes.com/lifestyle/health-fitness/health-news/All-yoneed-to-know- (January29, 2016)].

There is no commercial vaccine or antiviral drugs for Zika virus infection. So, the only possible ways to prevent from the virus infection is by using insect repellent such as DDT, using mosquito nets while sleeping; 
empty, clean or cover containers to stop the possible mosquito breeding [Fauci et al., 2016].

Zika outbreak is worse than the Ebola outbreak of 2014-15 as it is a silent infection in pregnant woman with foetal deformation (microcephaly) which lead to terrible effects in new borns with underdeveloped brains and retarded physical development as well as severe neurological condition in infected adults with Guillain- Barre's syndrome [http://www.theguardian. com/world/ 2016 /jan/30/zika-virus-health-fears (accessed on 1st February, 2016); http://www.wpro.who.int/ mediacentre/ facts heets /fs_05182015_zika/en/ (accessed on January, 2016)]. This is a real curse for the entire mankind.

Therefore early vaccine development to tackle the virus is a global emergency. But the real problem behind vaccine trials is that it has to be tested on pregnant women which are ethically questionable.

\section{References}

Fauci, Anthony, S., Morens, D.M. 2016. Zika virus in the Americas yet another arbovirus threat. New Eng. J. Med., 374(2): $\quad 160113142101009$ doi: 10.1056/NEJMp1600297.PMID26761 185.

http://timesofindia.indiatimes.com/lifestyle/health-fitness/health-news/Allyo-need-to-know- (January29, 2016)

http://www.cdc.gov/zika/geo/ (accessed on February 3, 2016)

http://www.theguardian. com/world/ 2016 /jan/30/zika-virus-health-fears (accessed on 1st February, 2016)

http://www.wpro.who.int/ mediacentre/ facts heets /fs_05182015_zika/en/ (accessed on January, 2016)

\section{How to cite this article:}

Shaheen Shah and R.N.S. Yadav. 2016. Combating Zika Virus becomes a Global Concern. Int.J.Curr.Microbiol.App.Sci. 5(9):271-272. doi: http://dx.doi.org/10.20546/ijcmas.2016.509.030 